\title{
An Intervention Model for a Risky Health Behavior in Minorities Facing Cultural and Global Health Challenges: The Case of Twalèt Déba (Feminine Hygiene)
}

\author{
Clarence St Hilaire ${ }^{1 *}$, Aisha Harris-Smith $\operatorname{Cox}^{2}$, Satyajit Patra ${ }^{2}$ and Sahana Salins ${ }^{2}$ \\ ${ }^{1}$ Health Psychology at Northcentral University, USA
}

${ }^{2}$ American International Medical University, St. Lucia

Submission: October 30, 2017; Published: November 21, 2017

*Corresponding author: Clarence St Hilaire, Health Psychology at North central University, American International Medical University, St. Lucia USA, Email: klarynz@gmail.com

\begin{abstract}
This article focuses on the linkage between a worldwide culturally practiced feminine hygiene, considered by many as a health risk behavior, by four ethnic groups: Haitian, Mexican, Latina and Turkish women termed twalèt déba (vaginal cleanliness), and the human papilloma virus (HPV) leading to cervical cancer. A necessary debate warrants further analysis because the factors leading to HPV were not fully explored by previous research endeavors; and the connection between the practice and cervical cancer is not clearly exposed. The cultural and health behavior determinants are not easily framed for a deep understanding of the epidemiological and on ecological tentacles of this feminine practice. There are also elements of socio-economic disparities seen as barriers to HPV testing. A human papilloma virus disparity intervention model is proposed (HPVDIM) as the first assessment tool created prior to the current existing interventions of HPV testing and HPV vaccine. The contribution can be positively appreciated considering the void existing in the literature.
\end{abstract}

Keywords: Feminine hygiene; twalèt déba; Risky behavior; HPV; Cervical cancer; HPVDIM

\section{Introduction}

This paper presents an intervention model for a risky behavior linked to the human papilloma virus (HPV), and cervical cancer, in four minorities (Haitian women, Mexican immigrant women, other Latinas (Hispanic) and Turkish women) facing cultural/traditional, religious, and global health challenges, termed as Twalèt Déba (feminine hygiene) in Haitian culture, vagina cleanliness with water and soap, or genital hygiene, and douching inothers [1-8]. Vaginal douching is widely performed worldwide, and is defined as a practice that entails washing the vagina with water, or other solutions to ensure a sense of cleanliness, tightness, elimination of discharge, dictated by cultural or religious mores, and to prevent pregnancy $[8,9]$.

The risk factors associated with HPV vary: vulvovaginal candidias is, pelvic inflammatory disease (PID), preterm delivery, cervical carcinoma, urinary tract infection, sexually transmitted disease (STI), and ectopic pregnancy [8,9]. The HPV disparity and intervention model (HPVDIM) [10] is intended to be a preventive scale, which can be used prior to HPV testing, adherence to research protocols, and participation in community health projects. The scale will allow researchers to determine levels of awareness and knowledge in individuals susceptible to HPV, and community organizations, or other institutions' readiness in providing services and testing, within the parameters of evidence based interventions. It can be understood under the purview of several health and social psychology frameworks that are specifically congruent with the bio-psychosocial model, social ecological model of prevention, the health belief model (HBM), and the general self-efficacy (GSE) theory.

The literature surveyed showed a lack of HPV scale, when compared with some HPV vaccination scales, and scant questionnaires [11-13]. The research project presents an overview of the human papillomavirus (HPV) and cervical cancer in targeted populations, and worldwide.

The following preliminary research questions formulated are enunciated below: 
a. How can HPV prevention and knowledge enhance the understanding or cervical cancer?

b. What kind of outcome will an enhanced comprehension of HPV, and cervical cancer have on the cultural/religious practices of feminine hygiene (Twalèt déba), and other cultural contexts?

c. How can the amalgamation of HPV prevention and knowledge, cervical cancer knowledge, and cultural perspectives within these populations impact incidence and prevalence rates of cervical cancer, and STI (sexually transmitted infections)?

d. To what extent can evidence-based interventions and community resources sustain HPV testing rates in the minority populations?

e. What could be the effects of the HPVDIM scale on the minority populations?

\section{Overview of HPV, cervical cancer worldwide, and targeted populations}

According to the Department of Health and Human Services (DHSS), Center for Disease Control and Prevention, and the National Cancer Institute 2017, although cervical cancer has decreased for the past 40, or 50 years [14], in 2014, 12,578 women in the United States were diagnosed with cervical cancer; and 4,115 women in the United States died from cervical cancer. Such alarming trend indicates that awareness, knowledge, preventive measures, and the risks associated with cervical cancer, are more than ever important in the fight to minimize the root causes, sustain disease control, or health protection measures, and policy formulations.

The Center for Disease Control and Prevention, Behavioral Risk Factor Surveillance System, reported that women ages 2165 who received a Pap smear in the past 3 years, by State, 20002010 totaled $84.4 \%$. The District of Columbia had the highest percentage in the nation with $91 \%$. In California, the rate was $85 \%$ in 2010. However, in Turkey, pap smear is taboo; and for young girls, it implies premarital sex, which is sanctioned [15]. In steady course with the causes of cervical cancer, infection from the human papillomavirus (HPV) was the leading indicator of all cervical cancers in Florida in 2010. The percentage was $82.6 \%$ in 2014; and HPV was among the most sexually transmitted disease in the United States. The American College of Obstetrics and Gynecologists (ACOG) recommends that women between the ages $20-31$ be tested every 2 years. Women age 30 or greater who had 3 consecutive negative test results, may be screened one time every 3 years.

A look at Turkey showed a population of 30.11 million women aged 15 years and older at risk for developing cervical cancer. The crude incidence rates of HPV-related cervical cancer were $4.5 \%$, with an annual incidence of 1686 , and mortality of 683 in 2017.Cervical cancer ranks as the 11th leading cause of women cancer in Turkey [16] reported that HPV was the second leading cause of cancer-related mortality among women worldwide. To foster awareness, disease control, in order to improve health, and health behavior changes, the National Prevention Strategy of the United States Department of Health and Health Services postulates four strategic directions to guide the nation's prevention efforts towards diseases [17].

The directions enunciated are:

a. Health and safe community environments.

b. Clinical and community preventive services.

c. Empowerment of people.

d. Elimination of health disparities.

\section{Health disparities}

According to Garcini et al. (2015), across ethnic lines there are serious issues of disparities in awareness, and knowledge of HPV infections among 1st and 2nd generation Asian-Americans, and 1 st and 2nd generation Latinas in California. Latina women suffered great disparities compared to other ethnic groups in cervical cancer screening rates attributed to Pap smear [1]. The main disparities consisted of socioeconomic, cultural factors, and high-risk behaviors. In Florida, Haitian immigrant women in Little Haiti, in Miami Dade County face the same issues of awareness and knowledge of HPV, multiple barriers to Pap smear screening, high-risk behaviors relating to inequitable health access, language barriers (lack of English), socio-cultural factors, fear of deportation, perceived susceptibility, and perception of health and illness $[6,7,14]$.

Cervical cancer is a public health issue affecting not only Asian-Americans, Latinas (Hispanic women), and Haitian women in Little Haiti, Miami, Florida, but a broad spectrum of women statewide, communities, and social institutions [14]. In Turkey, the disparities linking socioeconomic factors with sociodemographic characteristics (age, religion, place of residence, and poverty) have influences women's attitudes towards douching, but the perceptions of health seemed to be tied to practices and beliefs of feminine hygiene of cleanliness, religious and cultural factors. A complete assessment is needed $[4,8,9]$.

The CDC [18] estimated that from the 11,700 new cases of HPV-associated cervical cancer diagnosed annually in the United States, Blacks and Hispanic women have a higher rate of HPVassociated cancer than Whites. The reasons are tied to limited access to pap testing and follow-up [19]. In Miami-Dade County, Florida, cervical cancer is about $8.9 \%$ compared to the USA rate of $7.6 \%$, although the age-adjusted rate case per 100,000 is 10.2 average annual count of 147 . The Florida Behavioral Risk Factor Surveillance System (BRFSS) survey reported in 2010 an incidence of 857 new cases of cervical cancer diagnosed, with a mortality rate of 312 . Racial and foreign-born, and medically needy women experience increased risk of developing and dying 
from cervical cancer due to their deprived economic status, lack of access, and underutilization of screening [20]. The Haitian women in Little Haiti in Miami Dade County fit this category.

The socio demographic data shows income below the poverty level. Nonetheless, the lack of specific research targeting the risk factors associated to cervical cancer (smoking, increased fullterm pregnancies, long termused of contraceptives, and multiple sexual Partners) [21] for this population suggests the problems associated with HPV are deeply rooted. Risk factors associated with HPV for Turkish women consisted of disturbances in vaginal flora, ectopic pregnancy, PID, cervical cancer, preterm delivery, endometritis, and upper genital tract infections $[4,8,9]$.

\section{Populations}

The literature presents a vast array of women. Four hundred and five Haitian women(Haitian descent and Haitian born) living in Little Haiti, an enclave in Miami-Dade County, Florida, a purposive sample of 20 Mexican immigrant women in California, a meta-synthesis of 9studies of women consisting of 668 participants originated from Latin and South American countries, and the Caribbean islands; and 3 sample sizes of 1419 Turkish women who perform traditional genital hygiene consisting of douching, and application of other substances for genital health and sexual activities, consisted the backbone of this intervention research project $[1,4-8,10,20,22,23]$. The Turkish populations consisted of three research types: a) a cross-sectional study conducted at a women and child hospital in Istanbul with a sample size of 178 women, age range of cases 20-60. b) a study in Antalya with a sample size of 776 women, aged between 15-44 years, and c) another cross-sectional study of 465 Muslim women in Matalya, aged 15-49 years.

\section{Barriers to Pap Smear Screening}

The Haitian, Latinas (Hispanic women), and Mexican immigrant women were all related to a low socioeconomic status(SES) with regards to their inabilities for screening such as Papanicolaou (Pap smear) test [24,25] and lack of access to preventive health services, curative treatment or palliative care $[1,17,24]$. McMullin [5] posited that the Latina (Hispanic women) immigrants' lack of health insurance is an economic factor that inhibits HPV screening, and culture as well, which include beliefs about cervical cancer such as "immoral", fatalism and knowledge. For the Haitian women the degree of dependence on their partners, and willingness to improve their sexual pleasure, citizenship and immigration status, language and socio-cultural factors, are considered as forms of barriers [7].

The Turkish populations showed a lack of knowledge, and communication confined within certain schemes associated with religion, fear of premarital sex perceptions, which is taboo and sanctioned in the society [9]. Perceived as a normal behavior, vaginal douching, or twalèt déba continues to guide their beliefs and concerns. The related attitudes of the eastern Turkey Muslim women, associated with the sample size of 465 show a correlation between their educational levels as literate, totaling 366 , and high school level of 99 , were also considered as barriers [25].

\section{The role of genotyping and ill-assessed risk factors}

The ongoing research on the role of cancer biomarkers leading to cervical dysplasia among the Haitian [26], Latinas (Hispanic women), Mexican immigrant women, and Turkish women to arrive at an HPV type or types for vaccination promotion is well researched in the literature $[4,23,27]$. Nonetheless, the guideline for assessing HPV types 16, 18 genotyping for minority women in the U.S, and Turkish women with cervical cancer seem to evolve $[23,28]$, require closer scientific inputs, and large scales analysis and revisions.

The results linking vaginal douching (VD) and twalèt déba to Types 16 and 18 appear to be objectively or scientifically warranted, and juxtaposed with other factors not considered. The reason could be due to HPV types or variants, or the lack of variant types for all the risk factors associated with cervical cancer. Another consideration is the silence by most of the researchers to link a specific type of feminine hygiene causing vaginal or cervical mucosa erosions that lead to HPV and cervical cancer. More needs to be done to completely assess cervical and vaginal mucosal lesions associated with vaginal douching only, and Twalèt déba, although HPV 16 and 18 accounts for $70 \%$ of cervical cancers globally [27]. In terms of epidemiology, it would be asinine not to report that epidemiology statistics show that HPV 16 and 18 are the most compelling carcinogens for all highrisk types.

\section{The missing link about twalèt déba and douching}

Inexistent in the researchers surveyed is the controversial scientific literature linking cervical and vaginal lesions resulting from douching, and or Twalèt déba to the types of vaginal chemical agents used such as boric acid (borasol, boron) dissolved powder in water with the effects of cleansing and tightening the vagina, and other feminine agents: lemon juice, castor oil, pigeon pea (pwa congo), aloe vera, potassium permanganate [7]. In the Haitian culture, douching (VD) is also practiced after a woman gives birth. Douching refers to sitzbaths (vapors) consisting of aromatic leaves: papaya, sour orange, sour soup (corossol), and mint (tibaume), anise, bugleweed and eucalyptus that the woman uses in her first post-partum days to relax and tighten the cervix and vagina. The same leaves are also used for teas [29].

Mandal \& Balodi [30] reported acetic vinegar, functioning as an acidifying agent, and sodium bicarbonate as an alkalizing agent among the many types of vaginal products used by women. DHHS report on the background and environmental exposure to boron(boric acid) in the United States showed that exposure to boric acid is through ingestion of food, and in drinking water generally range from $<1$ to $3 \mathrm{mg}$ boron (boric acid). However, exposure to higher doses can be fatal (p.1). Furthermore, no epidemiology studies have identified an association between 
boron exposure and development of cancer (p.13).The ill effects of most of these agents: lemon juice, croton flavens, pigeon pea, potassium permanganate, potassium aluminum sulfate, and boric acid with water used by Haitian women, water and/ or other solutions for Latinas (Hispanic women), Mexican immigrant women, and Turkish women, have not been fully studied in relation to their potential effects, and codified in the literature.

For example, epidemiological studies have linked boric acid to upper respiratory and ocular irritations, and no associations were found between exposure to boric acid and indices of infertility in Turkish women [31], and boron mining and processing workers in California [32,33] studied 1,059 rural Turkish women and applied higher boron (boric acid) intake about 8 times exponentially higher urinary boric acid concentration, with lower incidences of cervical cancer. The National Institute for Occupational Safety and Health (NIOSH) reports that exposure to potassium permanganate on the skin leads to redness, skin burn, and pain. The preventive measures recommended are to wear gloves, and protective clothing. Longterm exposure may affect the lungs, resulting in bronchitis and pneumonia (NIOSH). The hypotheses generated from these studies were paramount, but the causal relationships between the feminine hygiene agents, their chemical and pharmaceutical agents and HPV and cervical cancer, warrant further studies. The HPV type attributions should also be examined under the oncogenic lens due to their predispositions to cervical cancer (dysplastic squamous cells with raisinoid nuclei and hyperchromasia) [21]. A patient's complete history is essential.

\section{Theoretical models}

Theoretical frameworks are important to understand the women's health and wellbeing, where socio cultural and religious determinants are highly important. In this intervention project, Bandura's social cognitive theory (SCT) is associated with the biopsychosocial model for a better appreciation of the determinants of health, and how social factors influence human development and actions [34]. SCT describes factors that influence behavior through a multilevel scheme [35]. The bio-psychosocial model recognizes the equal importance of the psychological, and social factors, and posits that interactions can be multi factorial $[36,37]$. The proposed intervention embraces the same approach claiming that CBR (community-based resources, EBI (evidencebased interventions), and the participants' risk factors leading to cervical dysplasia can be mustered for analysis and confirmation.

The above theoretical framework bio-psychosocial model is congruent with the social ecological model of prevention, the health belief model (HBM), and the theory of planned behavior (TPB). These theories can nicely correlate with the implementation or an awareness campaign about cervical cancer screening testing. In the health belief model, an individual considers his or her participation in a prevention programs if there is a perceived susceptibility, perceived severity, perceived benefits, barriers, promptness to action, based on confidence in their actions[(self-efficacy) [26]. The social ecological model of prevention asserts that a disease prevention continuum needs to have 4 pillars: a set of individual's beliefs and influence, an interpersonal framework of influence, a community apparatus to sustain the degree of influence, and finally societal influences. The theory of planned behavior (TPB) advances that there is an underlying behavior intention that drives an individual's perception and towards a behavior evaluation.

\section{The HPV Disparity and Intervention Model (HPVDIM)}

As enunciated earlier, the HPV Disparity and Intervention Model (HPVDIM) seeks to be a scale serving as a bridge between the participants exhibiting high risk behaviors related to the feminine hygiene practice known as douching, and Twalèt déba, community organizations, or other institutions involved in the implementation of policies, evidence-based interventions aimed at increasing HPV testing, or screening to decrease cervical cancer rates. Currently, there is not a research that utilizes a combined scale to assess beliefs, knowledge, community- based resources, and evidence-based interventions. The closest scales are: the Carolina HPV Immunization Attitudes and Beliefs Scale [36] which measures parents' attitudes and beliefs towards vaccination, a survey research assessing current levels of awareness and knowledge, and HPV-related beliefs of a racially diverse population of students from Florida State University (FSU), and Florida Agricultural and Mechanical University (FAMU) [12] a mailed self-administered questionnaire to 500 university students to evaluate knowledge, attitudes and behaviors about HPV [13] Haitian immigrant women's knowledge, attitudes and beliefs regarding HPV vaccination towards their daughters [22], the California Health Interview Survey assessing health disparities in awareness and knowledge of HPV among ethnically diverse women and a study identifying differences in knowledge and attitudes about HPV among Black and White women in Person County, North Carolina.

The model is construed upon six pillars:

a. HPV scale

b. Participants

c. HPV beliefs scale

d. HPV knowledge scale

e. $\quad$ CBR (community-based resources)

f. Evidence-based interventions (EBI)

The HPV disparity and intervention model (HPVDIM) consists of 25 questions. Each scale consists of 5 items questions to assess perceived barriers to screening, perceived effectiveness, beliefs, knowledge, role of the community-based resources, and EBI. The scales will allow researchers to determine levels of awareness and knowledge in individuals susceptible to HPV, and community organizations, or other institutions' commitment to 
action The 25 questions/items are assigned a range of 2-4-points each. The total score is 100 . Higher values indicate higher perceived effectiveness, beliefs, knowledge, CBR role, and EBI.
The proposed model is depicted in Figure 1 together with the content of the HPV scale. Table 1 shows the HPV scale.

Table 1: The HPVDIM Scale.

\begin{tabular}{|c|c|c|c|c|}
\hline Participants & HPV Knowledge & HPV Beliefs & CBR & EBI \\
\hline $\begin{array}{l}\text { I never experienced } \\
\text { HPV screening } \\
\text { before } \\
\text { Score: }\end{array}$ & $\begin{array}{l}\text { HPV is related to } \\
\text { having sex without } \\
\text { a condom } \\
\text { Score: }\end{array}$ & $\begin{array}{c}\text { I practice vaginal } \\
\text { douching/Twalèt déba } \\
\text { as part of my } \\
\text { cultural/religious } \\
\text { beliefs } \\
\text { Score: }\end{array}$ & $\begin{array}{l}\text { I think there are } \\
\text { good organizations } \\
\text { or community } \\
\text { centers that can } \\
\text { help } \\
\text { Score: }\end{array}$ & $\begin{array}{l}\text { There are various } \\
\text { studies linking } \\
\text { HPV with } \\
\text { cervical cancer } \\
\text { Score: }\end{array}$ \\
\hline $\begin{array}{l}\text { I think HPV testing } \\
\text { is a safe procedure } \\
\text { Score: }\end{array}$ & $\begin{array}{l}\text { Having HPV } \\
\text { suggests that I } \\
\text { am an immoral } \\
\text { woman } \\
\text { Score: }\end{array}$ & $\begin{array}{c}\text { I have been } \\
\text { practicing vaginal } \\
\text { douching/Twalèt } \\
\text { déba as part of my } \\
\text { feminine hygiene, } \\
\text { and to enhance my } \\
\text { sexual experience } \\
\text { Score: }\end{array}$ & $\begin{array}{l}\text { How can I find a } \\
\text { good organization } \\
\text { that provides } \\
\text { HPV screening? } \\
\text { Score: }\end{array}$ & $\begin{array}{l}\text { How effective is } \\
\text { the HPV } \\
\text { screening } \\
\text { intervention } \\
\text { program? } \\
\text { Score: }\end{array}$ \\
\hline $\begin{array}{l}\text { I do not have health } \\
\text { insurance. HPV } \\
\text { screening can be } \\
\text { costly } \\
\text { Score: }\end{array}$ & $\begin{array}{l}\text { I don't have } \\
\text { enough } \\
\text { information } \\
\text { about HPV } \\
\text { Score: }\end{array}$ & $\begin{array}{l}\text { HPV can be a } \\
\text { problem to } \\
\text { someone's health } \\
\text { and cultural } \\
\text { practic }\end{array}$ & $\begin{array}{l}\text { How long do you } \\
\text { think you should } \\
\text { wait for an } \\
\text { appointment? } \\
\text { Score: }\end{array}$ & $\begin{array}{l}\text { If I am tested for } \\
\text { HPV, such } \\
\text { information is } \\
\text { very important to } \\
\text { prevent others } \\
\text { Score: }\end{array}$ \\
\hline $\begin{array}{l}\text { I have coverage } \\
\text { through my spouse } \\
\text { or a partner } \\
\text { Score: }\end{array}$ & $\begin{array}{l}\text { I think the HPV } \\
\text { vaccine is too new } \\
\text { for girls to get it } \\
\text { Score: }\end{array}$ & $\begin{array}{l}\text { In my culture, it is } \\
\text { taboo to have HPV } \\
\text { screening } \\
\text { Score: }\end{array}$ & $\begin{array}{l}\text { I don't have } \\
\text { transportation, and it } \\
\text { is hard for me to go } \\
\text { to the organization } \\
\text { Score: }\end{array}$ & $\begin{array}{l}\text { The HPV vaccine } \\
\text { has helped many } \\
\text { girls in my } \\
\text { community and } \\
\text { others } \\
\text { Score: }\end{array}$ \\
\hline $\begin{array}{l}\text { I am concerned } \\
\text { about HPV } \\
\text { because of my } \\
\text { sexual life } \\
\text { Score: }\end{array}$ & $\begin{array}{l}\text { I am concerned } \\
\text { about HPV } \\
\text { because of my } \\
\text { sexual life } \\
\text { Score: }\end{array}$ & $\begin{array}{l}\text { HPV screening } \\
\text { exposes someone's } \\
\text { premarital sex } \\
\text { privacy } \\
\text { Score: }\end{array}$ & $\begin{array}{l}\text { I am concerned that } \\
\text { the community } \\
\text { center may not be } \\
\text { able to help } \\
\text { Score: }\end{array}$ & $\begin{array}{l}\text { I was told about } \\
\text { cervical cancer } \\
\text { research resulting } \\
\text { from HPV } \\
\text { Score: }\end{array}$ \\
\hline Total & Total & Total & Total & Total \\
\hline
\end{tabular}

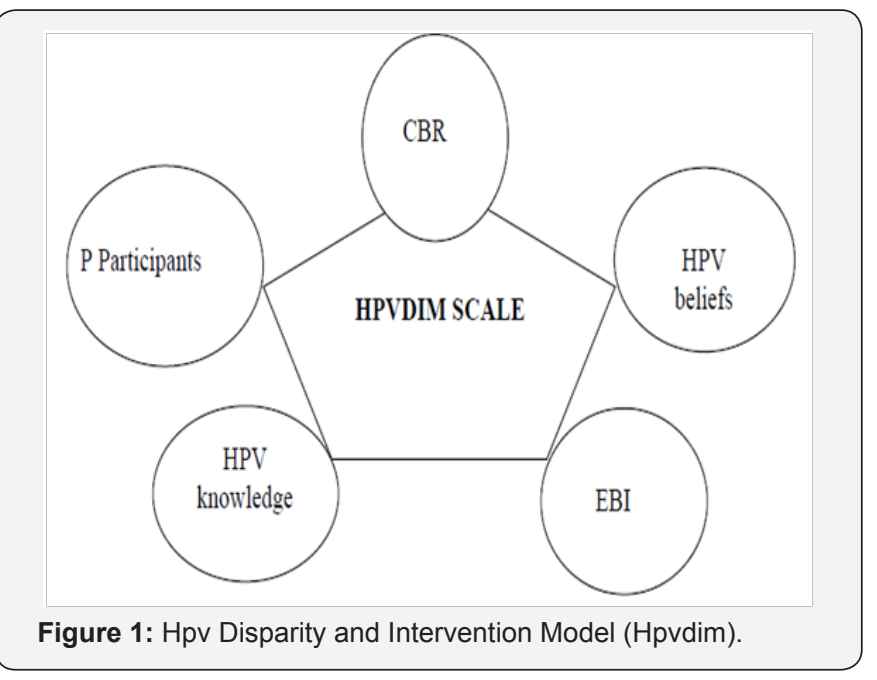

\section{The HPVDIM Scale}

The participant scale consists of the following 5 questions. Each is assigned a range between 2-4 points. (Please add your score between 2 and 4 next to each question).
a. I never experienced HPV screening before.
b. I think HPV testing is a safe procedure.
c. I do not have health insurance. HPV screening can be costly.

d. I have coverage through my spouse or a partner.

e. I am concerned about HPV because of my sexual life.

The HPV knowledge scale consists of the following 5 questions. Each is assigned a range between 2-4 points. (Please add your score between 2 and 4 next to each question). 
a. HPV is related to having sex without a condom.

b. Having HPV suggests that I am an immoral woman.

c. I don't have enough information about HPV.

d. I think the HPV vaccine is too new for girls to get it.

e. How effective is HPV in averting cervical cancer?

The HPV beliefs scale consists of the following 5 questions. Each is assigned a range between 2-4 points. (Please add your score between 2 and 4 next to each question).

a. I practice vaginal douching (VD)/Twalèt déba as part of my cultural/religious beliefs.

b. I have been practicing vaginal douching (VD)/Twalèt déba as part of my feminine hygiene, and to enhance my sexual experience.

c. HPV can be a problem to someone's health and cultural practices.

d. In my culture, it is taboo to have HPV screening.

e. HPV screening exposes someone's premarital sex privacy.

The community-based resources scale consists of the following 5 questions. Each is assigned a range between 2-4 points. (Please add your score between 2 and 4 next to each question).

a. I think there are good organizations or community centers that can help.

b. How can I find a good organization that provides HPV screening?

c. How long do you think you should wait for an appointment?

d. I don't have transportation, and it is hard for me to go to the organization.

e. I am concerned that the community center may not be able to help.

The evidence-based intervention scale consists of the following 5 questions. Each is assigned a range between 2-4 points. (Please add your score between 2 and 4 next to each question).

a. There are various studies linking HPV with cervical cancer.

b. How effective is the HPV screening intervention program?

c. If I am tested for HPV, such information is very important to prevent others.

d. The HPV vaccine has helped many girls in my community and others. e. I was told about cervical cancer research resulting from HPV.

\section{Strengths and limitations of the HPVDIM}

As the only model that incorporates HPV knowledge, HPV beliefs, the role of community based resources and evidencebased interventions, the HPVDIM model seems to position itself as a viable tool for health or social psychology research, and further interdisciplinary outlooks. However, the model has not been tested; and as such, its apparent limitations are clearly spelled out. It is limited to critical theories. Although the model can be understood as a contributor to paradigm change [38-41], its adherence to the research protocols has not been yet proven [42-44].

\section{Conclusion and Recommendations for Practice and Future Research}

In this intervention research article, the literature shows an association between HPV screening and cervical cancer linked to a specific risky health behavior in 4 minority populations, namely vaginal douching and Twalet déba for Haitian women in Miami. Questions of disparities attributed to socioeconomic status play a great role in the lack of HPV screening or testing, as well as women dependency on their sexual partners due to lack of income [45]. Cultural and religious beliefs are some of the barriers the women in these studies face. The literature associated with HPV types, as prevailing factors leading to cervical cancer, is not cohesively complete. Many questions about the risks factors associated to HPV, and cervical cancer, based on the cultural hygiene practices seem to persist [46]. The recommendation is to use the HPVDIM scale as aninter disciplinary tool to advance the research inquiries towards new paradigms and solutions. It is hoped that the intellectual inquiry will continue as new research boundaries are formed [47]. The HPVDIM seems to be one of them.

\section{References}

1. Corcoran J, Crowley M (2014) Latinas attitudes about cervical cancer prevention: A meta synthesis. J Cult Divers 21(1): 15-21.

2. Garcini LM, Murray KE, Barnack TJL, Zhou AQ Malcarne VL, et al. (2015) Awareness and knowledge of human papilloma virus (HPV) among ethnically diverse women varying in generation status. J Immigr Minor Health 17(1): 29-36.

3. Kobetz E (2008) Pap Tes Lakay: a cervical cancer intervention in little Haiti. Sylvester Comprehensive Cancer Center. University of Miami, Florida, USa.

4. Kukulu K (2006) Vaginal douching practices and beliefs in Turkey. Cult Health Sex 8(4): 371-378.

5. McMullin J, De Alba I, Chavez LR, Hubbell FA (2005) Influence of beliefs about cervical cancer etiology on Pap smear use among Latina immigrants. Ethn Health 10(1): 3-18.

6. Ménard J, Kobetz E, Diem J, Lifleur M, Blanco J, et al. (2010) The sociocultural context of gynecological health among Haitian immigrant women in Florida; applying ethnographic methods to public health inquiry. Ethn Health 15(3): 253-267. 
7. Ménard J (2010) Barriers to cervical cancer screening among Haitian immigrant women in Little Haiti, Miami. J Cancer Educ 25(4): 602-608.

8. Yaman HE, Aygun M, Tosun H (2016) Traditional genital hygiene practices in Turkey. Indian Journal of Traditional Knowledge 15(2): 214218.

9. Ege E, Timur S, Zincir H, Egri M, Sunar RB (2007) Women douching practices and related attitudes in eastern Turkey. J Obstet Gynecol Res 33(3): 353-359.

10. Hilaire SC (2017) Applying theories and models of behavior health change. A white paper construct. Unpublished paper Health psychology course PSY8300.

11. Cates JR, Brewer NT, Fazekas KI, Mitchell CE, Smith JS (2009) Racial differences in HPV knowledge, HPV vaccine acceptability, and related beliefs among rural, Southern women. J Rural Health 25(1): 93-97.

12. Gerend MA, Magloire ZF (2008) Awareness, knowledge, and beliefs about human papillomavirus in a racially diverse sample of young adults. J Adolesc Health 42(3): 237-242.

13. Yacobi E, Tennant C, Ferrante J, Pal N, Roetzheim R, et al. (1999) University students' knowledge and awareness of HPV. Preventive Medicine 28(6): 535-541.

14. Daley E, Alio A, Anstey EH, Chandler R, Dyer K, et al. (2011) Examining barriers to cervical cancer screening and treatment in Florida through a socio-ecological lens. J Community Health 36(1): 121-131.

15. Bieber S (2014) Pap smear: Cervical cancer screening remains taboo in Turkey.

16. ICO Information Center on HPV and Cancer (2017) Human papillomavirus and related cancers.

17. WHO (2016) Screening as well as vaccination is essential in the fight against cervical cancer.

18. CDC, DHHS, National Cancer Institute (2016) U.S. Cancer Statistics Working Group. United States Cancer Statistics: 1999-2013 Incidence and Mortality Web-based Report.

19. Viens LJ, Jane HS, WatsonM, Lauri EM, Cheryll CT, et al. (2016) Human papilloma virus associated cancers. United States 2008-2012.

20. Barbee L, Kobetz E, Menard J, Cook N, Blanco J, et al. (2010) Assessing the acceptability of self-sampling for HPV among Haitian immigrant women: CBPR in action. Cancer Causes Control 21(3): 421-431.

21. Le T, Bhushan V, Sochat M (2015) First Aid for the USMLE Step 1. McGraw Hill, New York, USA.

22. Joseph NP, Clark JA, Bauchner H, Walsh JP, Mercilus G, et al. (2012) Knowledge, attitudes, beliefs regarding HPV vaccination: Ethnic and cultural differences between African-American and Haitian immigrant women. Women's Health Issues 22(6): e571-e579.

23. Schiffman M, Boyle S, Raine BT, Katki HA, Gage JC, et al. (2015) The role of human papillomavirus genotyping in cervical cancer screening: A large-scale evaluation of the cobas HPV test. Cancer Epidemiol Biomarkers Prev 24(9): 1304-1310.

24. Datta GD, Colditz GA, Kawachi I, Subramanian SV, Palmer JR, et al (2006) Individual, neighborhood, and state-level socioeconomic predictors of cervical carcinoma screening among U.S. black women: a multilevel analysis. Cancer 106(3): 664-669.

25. Kish JK (2012) Culture and context: Upstream determinants of cervical cancer among Haitian immigrants living in Miami, Florida (Unpublished doctoral dissertation.) University of Miami, Florida.

26. Glanz K, Rimer BK, Lewis FM (2002) Health behavior and health education: Theory, research, and practice ( $3^{\text {rd }}$ edn.). San Jossey-Bass, Francisco, Calif.
27. Hariri S, Unger ER, Schafer S, Niccolai LM, Park IU, et al. (2015) HPV type attribution in high-grade cervical lesions: Assessing the potential benefits of vaccines in a population-based evaluation in the United States. Cancer Epidemiol Biomarkers Prev 24(2): 393-399.

28. ICO Information Center on HPV and Cancer (2017) Human papillomavirus and related diseases.

29. Colin J, Paperwall G (2003) Haitians. In: Hill PS, Lipson JG, Meleis AI (Eds.), Caring for women cross-culturally Philadelphia, pp. 172-187.

30. Mandal G, Raina D, Balodi G (2014) Vaginal douching: methods, practices and health risks. Health Sciences Research 1(4): 50-57.

31. Sayli BS (1998) An assessment of fertility in boron-exposed Turkish subpopulations. Evidence that boron has no effect on human reproduction. Biol Trace Elem Res 66(1-3): 409-422.

32. Whorton D, Haas J, Trent L (1994) Reproductive effects of inorganic borates on male employees: Birth rate assessment. Environ Health Perspect 102(Suppl 7): 129-132.

33. Korkmaz M, Uzgoren E, Bakirdere S, Aydin F, Ataman OY (2007) Effects of dietary boron on cervical cytopathology and on micronucleus frequency in exfoliated buccal cells. Environ Toxicol 22(1): 17-25.

34. Lammle L, Worth A, Bos K (2010) A Biopsychosocial process model of health and complaints in children and adolescents. J Health Psychol 16(2): 226-235.

35. Bandura A (2004) Self-efficacy: The exercise of control. Freeman, New York, USA.

36. McRee AL, Brewer NT, Reiter PL, Gottlieb SL, Smith JS (2010) The Carolina HPV immunization attitudes and beliefs scale (CHIAS): Scale development and associations with intentions to vaccinate. Sex Transm Dis 37(4): 234-239.

37. Garroway AM, Rybarczyk B (2015) Aging, chronic disease, and the bio-psychosocial model. In: Lichtenberg PA and Mast BT (Eds.), APA Handbook of Clinical Geropsychology. American psychological association pp. 563-622.

38. Kuhn TS (1996) The structure of scientific revolutions. ( $3^{\text {rd }}$ edn), The University of Chicago Press, Chicago, USA.

39. BRFS (2010) Florida Health Cervical cancer in Florida. Florida Department of Health, Division of Disease Control and Health Protection, Bureau of Epidemiology.

40. CDC, DHSS, National Cancer Institute (2017) Based report: Dept. of Health \& Human Services.

41. CDC, NIOSH (2017) Potassium permanganate.

42. Florida health gov (2010) Cervical cancer in Florida. Florida Department of Health, Division of Disease Control and Health Protection, Bureau of Epidemiology.

43. National Cancer Institute (2005) Theory at a glance. A guide for health promotion practice. US Department of Health and Human Services and NIH.

44. National Prevention Council. (2014) National prevention strategy Office of the Surgeon General. Rockville, US.

45. The National Institute for Occupational Safety and Health (2003) Potassium permanganate.

46. U.S. DHHSS Agency for Toxic Substances \& Disease Registry (2011) Tox Guide for Boron B. Case \# 7440-42-8.

47. https://www.cdc.gov/cancer/hpv/statistics/cases.htm. 
This work is licensed under Creative Commons Attribution 4.0 Licens

DOI: 10.19080/JGWH.2017.07.555715
Your next submission with Juniper Publishers will reach you the below assets

- Quality Editorial service

- Swift Peer Review

- Reprints availability

- E-prints Service

- Manuscript Podcast for convenient understanding

- Global attainment for your research

- Manuscript accessibility in different formats

( Pdf, E-pub, Full Text, Audio)

- Unceasing customer service

Track the below URL for one-step submission https://juniperpublishers.com/online-submission.php 